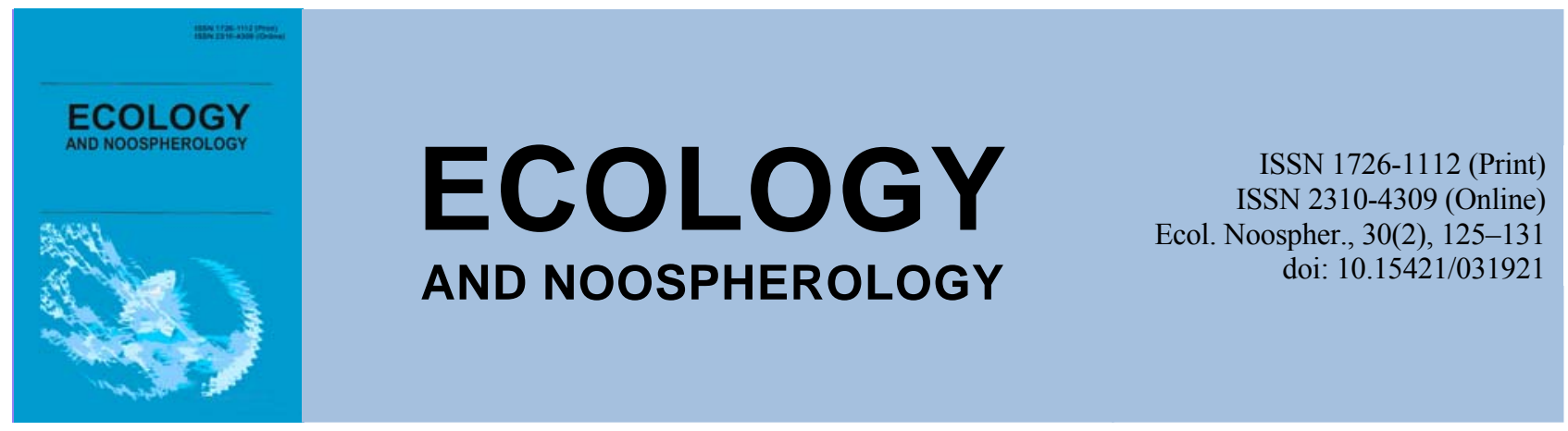

\title{
Hydrological and hydrobotanic typology of the lake of North-Steppe Dnieper region
}

\author{
N. O. Roshchyna, B. O. Baranovski \\ Oles Honchar Dnipro National University, Dnipro, Ukraine
}

Article info

Received 03.09.2019

Received in revised form 12.09.2019

Accepted 20.09.2019

Oles Honchar Dnipro

National University,

Gagarin Ave., 72, Dnipro, 49010, Ukraine.

Tel.: +38-097-774-43-27

E-mail: botanik_N@ua.fm
Roshchyna, N. O., Baranovski, B. O. (2019). Hydrological and hydrobotanic typology of the lake of North-Steppe Dnieper region. Ecology and Noospherology, 30(2), 125-131. doi:10.15421/031921

This article is devoted to the typology of lakes of the North-Steppe Dnieper. In developing the typology of lakes, the parameters were taken into account: landscape location, hydro-chemical and hydro-biological characteristics and the degree of their anthropogenic transformation. The data presented are based on the processing of stationary and route research materials from 1998 to 2018 on the lakes of river valleys: Dnieper, Samara, and Orel. Hydrological indicators are analyzed according to the literature, cartographic and archival data of the Dneprodiprovodkhoz Institute and the Biology Research Institute of Oles Honchar Dnipropetrovsk National University. Floristic studies were carried out using general botanical methods of collection and herbarization, and in the study of typical aquatic flora - special hydro-botanical methods. Geo-botanical studies were carried out according to geo-botanical and special hydro-botanical methods. The article presents the hydrological and hydro-botanical features of the lakes of the valley of a large river (Dnieper) and medium rivers (Samara, Orel). Lakes are located exclusively in valley-terrace landscapes in the northern part of the steppe zone of Ukraine. Despite this, based on cartographic materials, we proposed zoning of the territory of the lakes of the North-Steppe Dnieper according to the criteria: their location in lake regions, in various landscapes and the degree of anthropogenic transformation. The following districts and subareas were identified: Dnieper Lake District (Dnieper floodplain lake subarea with slight flooding of the floodplain, Dnieper Lake subarea of floodplain terraces, Dievsky floodplain lake subarea); Samara Lake District (Lake Subarea of Samara Coniferous forest, Lake Subarea of Estuary part of Samara); Orel Lake District. Lakes are located in various physical and geographical conditions of the floodplain, arena and third saline terrace. The typology of the lakes of the North-Steppe Dnieper basin was developed on the basis of regionalization of the location of the lakes, distribution according to the ecological and topographic profile, hydrological, hydro-chemical regimes, degree and nature of overgrowing. 11 types of lakes are identified based on the above criteria. 6 types were identified for the valley of a large river: floodplain lakes (3 types) with a longflow regime, lakes of the second (sandy) terrace ( 2 types) and highly mineralized lakes of the third (saline) terrace. 5 types were identified for the valleys of middle rivers: floodplain lakes ( 3 types) with an episodic short-burial regime, lakes of the second (sandy) terrace (low-mineralized) and excessively mineralized lakes of the third (saline) terrace.

Keywords: typology of lakes; hydrological and hydro-botanical features; North-Steppe Dnieper; valley-terraced landscape

\section{Гідролого-гідроботанічна типологія озер північно-степового Придніпров'я}

\author{
Н. О. Рощина, Б. О. Барановський
}

Дніпровський національний університет імені Олеся Гончара, Дніпро, Україна

Ця стаття присвячена розробці типології озер північно-степового Придніпров’я. При іiі розробці були враховані ландшафтне розташування, гідрохімічні та гідробіологічні характеристики та ступінь їх антропогенної трансформації. Представлені дані отримані на основі матеріалів стаціонарних та маршрутних досліджень 1998-2018 рр. на озерах долин річок Дніпра, Самари, Орілі. В умовах північної частини степової зони України озера розташовані виключно у долинно- 
терасових ландшафтах. Зважаючи на це, нами на базі картографічних матеріалів запропоновано районування території розташування озер північно-степового Придніпров'я за критеріями їх розміщення в озерних районах, у різних ландшафтах та за різним рівнем антропогенної трансформації. Озера знаходяться в різних фізико-географічних умовах заплави, арени $\mathrm{i}$ третьої тераси. У статті надано гідролого-гідроботанічні особливості озер долини великої річки (Дніпра) та середніх річок (Самари, Орілі). На основі районування території розташування озер, розподілу за еколого-топографічним профілем, гідрологічним, гідрохімічним режимами, ступенем та характером заростання розроблено типологію озер північно-степового Придніпров'я. На основі наведених критеріїв виділено 11 типів озер. Для долини великої ріки виділено 6 типів: озера заплави (прируслові, центральнозаплавні, притерасні) з довгозаплавним режимом, озера другої (піщаної) тераси (від низькомінералізованих до високомінералізованих) та високомінералізовані озера третьої (солончакової) тераси. Для долин середніх річок виділено 5 типів: озера заплави (прируслові, центральнозаплавні, притерасні) з епізодично короткозаплавним режимом, озера другої (піщаної) тераси (низькомінералізовані) та надмірномінералізовані озера третьої (солончакової) тераси.

Ключові слова: типологія озер; гідролого-гідроботанічні особливості; північно-степове Придніпров'я; долиннотерасовий ландшафт

\section{Вступ}

В умовах північної частини степової зони України озера розташовані виключно у долинно-терасових ландшафтах, складові елементи яких відрізняються найбільш значним біорізноманіттям (Schindler et al., 2016).

Екосистеми озер при значній схожості мають і багато відмінностей: їх розміри та форма, трофіка, ступінь та характер заростання макрофітами. Існують приклади типологій континентальних водойм, у тому числі й озер (Gur'yanova, 1946; Sidel'nik, 1948; Polishchuk, Izumnova, 1983; Raspopov, 1985; Baranovsky, 1988, 2000). Але для степової зони України, де озера мають незначну площу, чисельність та екологічні відмінності, притаманні водоймам степової зони, окремої їх типології до цього часу не розроблено.

При розробці типології озер були враховані їх ландшафтне розташування, гідрохімічні та гідробіологічні характеристики та ступінь їх антропогенної трансформації.

\section{Матеріали та методи досліджень}

Матеріал був зібраний під час стаціонарних та маршрутних досліджень протягом 1998-2018 років на озерах долин річок у межах північної степової підзони степової зони України - Дніпра, Самари, Орілі (Baranovsky, 2002; Tarasov, Baranovskyj, 2003; Baranovskij, Voloshina 2010, 2012; Voloshina, 2014; Roshchyna, 2016, 2018; Manyuk, Baranovs'kij, Roshchina, 2018; Baranovs'kij, Tarasov, Ivan'ko et al., 2018).

Гідрологічні показники проаналізовано за літературними, картографічними та архівними даними Інституту Дніпродіпроводгосп та Науково-дослідного інституту біології ДНУ. Рівні мінералізації різних типів озер визначалися експрес-методом за допомогою сольоміру «Milwaukee», Conductivity Meter With ATC CD 601 та за матеріалами Інституту Дніпродіпроводгосп та НДІ біології ДНУ. Гідрохімічні показники наведено за літературними даними (Varenko, 1987; Varenko, Kovtun, Murzina, 1992; Baranovskyj, Loza, Murzyna, Delyja, 2002), даними гідрохімічної лабораторії Інституту Дніпродіпроводгосп, та гідрохімічної лабораторії НДІ біології та лабораторії хімії грунтів кафедри геоботаніки, грунтознавства та екології.

Флористичні дослідження проводилися 3 використанням загальноботанічних методів збору, гербаризації (Vyznachnyk roslyn Ukrai'ny, 1965), а при вивченні типової водної флори - спеціальних гідроботанічних методів (Katanskaja, 1981). Визначення видів здійснювалося за визначниками Vyznachnyk roslyn Ukrai'ny (1965), Opredelitel vysshih rastenij Ukrainy (1987), Flora Vostochnoj Evropy (1974-2004), Flora Evropejskoj chasti SSSR (1974-1989), Ekoflora Ukraïni (2000-2010). Сучасні назви рослин надано за зведенням, яке прийнято в
Україні - Mosyakin, Fedorochuk, 1999. Екоморфічний аналіз флори озер проводився за системою екоморф О. Л. Бельгарда (Belgard, 1950; Baranovski et al., 2018).

Геоботанічні дослідження проводилися згідно 3 геоботанічними (Polevaya geobotanika, 1964; Junatov, 1964) та спеціальними гідроботанічними методиками (Katanskaja, 1981).

\section{Результати та їх обговорення}

На території північно-степового Придніпров'я місця локалізації природних озер збігаються $з$ долинами великих річок. Зважаючи на це та спираючись на поняття «озерна область» В. І. Жадіна і С. В. Герда (Zhadin, Gerd, 1961), нами на базі картографічних матеріалів запропоновано районування території розташування озер північно-степового Придніпров'я (рис. 1) за критеріями їх розміщення:

- за озерними районами;

- за різними ландшафтами;

- за різним рівнем антропогенної трансформації (головним чином - підтоплення в результаті гідробудівництва).

\section{1. Дніпровський озерний район.}

1 a. Дніпровський заплавний озерний підрайон з незначним підтопленням заплави (природний заповідник «ДніпровськоОрільський»). У цьому підрайоні заплава Дніпра розвинута $\mathrm{i}$ має три типові еколого-топографічні зони, в яких розташовані озера:

1) прируслова заплава (озера Велика Лопатка, Мала Лопатка, Сомівка);

2) центральна заплава (озера Відлоге, Хомутці, Горіхове, Литвинове, Жовтеньке);

3) притерасні (озера Горбове, Сокілки, Солоне, Мала Хатка). Озера підтоплені водами Запорізького водосховища, більшість із них з'єднані між собою протоками.

1 б. Дніпровський озерний підрайон надзаплавних терас (II та III тераси).

Включає озера II тераси (озера Карпенкове, Саги, Московське, Шпакове нижнє, Чередницьке, Одинковка) та III тераси (озера Куряче, Куплевате, Вошивка).

1 в. Діївський заплавний озерний підрайон.

У систему основної протоки Річище входять озера Ріжок, Грузьке, Ковбаня, Іванцеве, Чисте Гирло. У східній частині заплави в районі житлових масивів «Червоний Камінь», «Комунар» $\mathrm{i}$ «Парус» утворене велике внутрішне плесо 3 численними островами i косами-насипами штучного походження, що розбивають його на декілька частин. Основу плеса складає оз. Болгарське, що існувало і до підйому води в p. Дніпро. Воно розділене островами на південну і північну частину, 3 півночі i заходу граничить із мілководними внутрішніми водоймами Діївської заплави: оз. Гадюче, зат. Рогози, оз. Скажене, прот. Протічка, оз. Гідропаркове. У центрі Діївської заплави по лівому березі прот. Річище розташовано ряд мілководних водойм: озера Вовче Горло, Глибоке, Копитянка, Плоске, Дубове. 


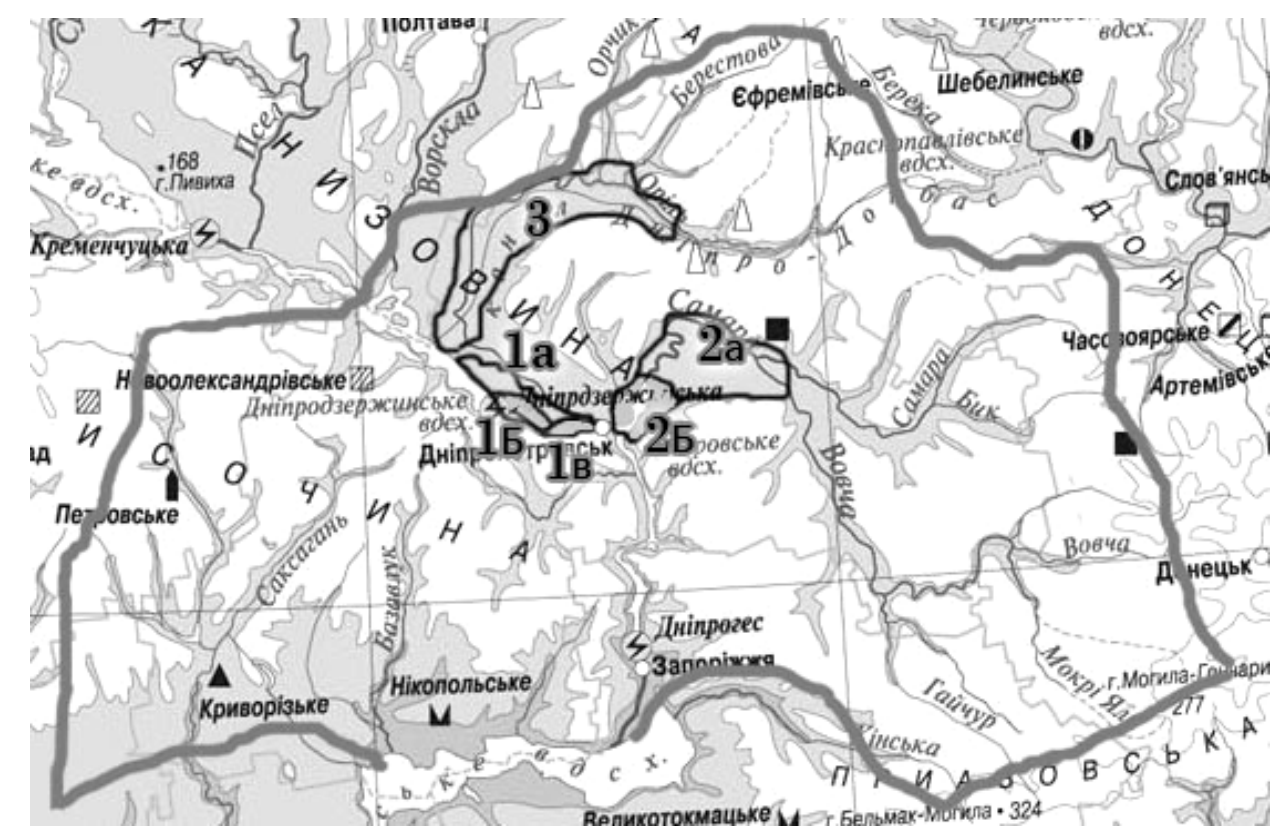

Рис. 1. Районування розташування озер у межах північно-степового Придніпров'я

\section{2. Самарський озерний район.}

2 a. Озерний підрайон Самарського бору.

У цьому підрайоні зберігся класичний екологотопографічний профіль, який вміщує I (заплавну), II (піщану) та III (солончакову) тераси. Заплава має три типові еколого-топографічні зони, в яких розташовані озера:

1) прируслова заплава (оз. Оленеве та багато маленьких озер, що не мають назви);

2) центральна заплава (озера Княгиня, Федорівське, Гайдамацьке та ін.);

3) притерасна заплава (озера Княгиня, Сорокособаче, малі лісові озера).

Арена займає велику площу, але озер там небагато. Найбільші з них озера Караванище та Корчаче.

На солончаковій терасі розташовані великі за площею озера Солоний Лиман та Булахівський лиман та ряд маленьких озер без назви.

2б. Озерний підрайон Пригирлової частини Самари (iз затопленням заплави). У гирловій частині русло р. Самара більш ніж на 40 км підтоплене водами Запорізького водосховища. Тут були затоплені усі заплавні озера та утворилася велика Самарська затока.

\section{3. Орільський озерний район.}

У долині Орілі через будівництво каналу та зміни в гідрологічному режимі в деяких місцях важко виділити тераси, а особливо зони заплави.

Гідролого-гідрохімічні та гідроботанічні відмінності озер. Озерні системи північно-степового Придніпров'я розташовані головним чином у долинах лівобережжя та частково правобережжя Дніпра $\mathrm{i}$ середніх річок лівобережжя (Оріль, Самара). Площа озер регіону в основному невелика - до 100 га, крім о. Солоного (300 га) та Козачого Лиману (150 га). У долині Дніпра озер 3 власним ім'ям нараховується 40, Орілі (з водоймами Проточі) - 100, Самари - 60.

Озера північно-степового Придніпров'я знаходяться в різних фізико-географічних умовах заплави, арени i третьої тераси. Згідно 3 класичним розподілом частин заплави за Раменським (Ramenskyj, 1938) вона поділяється на прируслову, центральну (центральнозаплавну), притерасну. Цьому розподілу відповідає і розташування озер, які В. I. Жадін (Zhadin, Gerd, 1961) назвав як прируслові, центральнозаплавні (заплавні ставки) та притерасні (притерасна річка).

Озера заплав відрізняються гідрокарбонатним та сульфатним класом води групи кальцію і середньою мінералізацією. Озера арен - гідрокарбонатним класом, групи кальцію і низькою мінералізацією. Озера третіх терас хлоридно-сульфатним класом, групи натрію і калію i високою або надмірною мінералізацією. Гідрологічні особливості основних типів озер долини великих річок (Дніпра) полягають у тому, що більшість озер заплави $\epsilon$ проточними або частково проточними. Загальна мінералізація знаходиться в межах 0,3-7 г/дм (табл. 1).

Гідрологічні особливості основних типів озер долин середніх річок (Самара, Оріль) відрізняються періодичною або незначною проточністю та більшим гідрохімічним діапазоном (від 0,1 до 40 г/дм3) (табл. 2). Озера долини Орілі відрізняються меншим, ніж у озер Самари, гідрохімічним діапазоном (від 0,3 до 7 г/дм3)

За розробленим районуванням (рис. 1) озера північностепового Придніпров'я розташовані в долинах річок

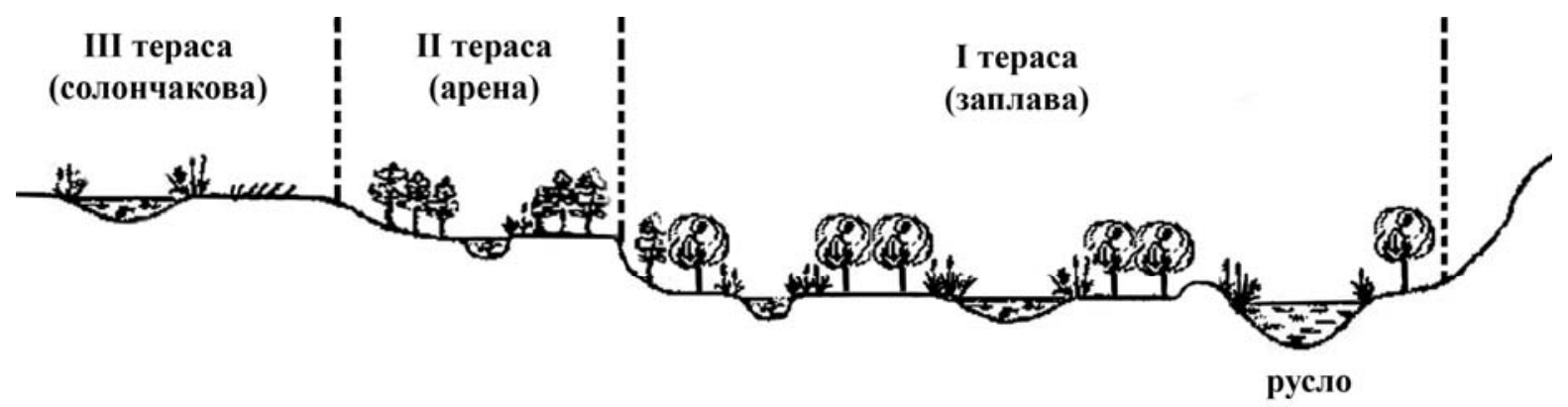

Рис. 2. Розташування озер у долинно-терасовому ландшафті 
Таблиця 1

Гідролого-гідроботанічні особливості озер долини великої річки (Дніпра)

\begin{tabular}{|c|c|c|c|c|c|c|}
\hline \multirow{2}{*}{$\begin{array}{r}\text { Типи } \\
\text { озер } \\
\text { Особ- } \\
\text { ливості } \\
\text { озер }\end{array}$} & \multicolumn{3}{|c|}{ Заплава } & \multicolumn{2}{|c|}{ Арена } & \multirow{2}{*}{\begin{tabular}{l}
\multicolumn{1}{c}{ 3-тя тераса } \\
Високо- \\
мінералізовані
\end{tabular}} \\
\hline & Прируслові & $\begin{array}{l}\text { Центрально- } \\
\text { заплавні }\end{array}$ & Притерасні & $\begin{array}{l}\text { Низько- } \\
\text { мінералі- } \\
\text { зовані }\end{array}$ & $\begin{array}{l}\text { Високо- } \\
\text { мінералізовані }\end{array}$ & \\
\hline $\begin{array}{l}\text { Особливості } \\
\text { гідрології }\end{array}$ & Проточні & $\begin{array}{l}\text { Періодично } \\
\text { проточні }\end{array}$ & $\begin{array}{l}\text { Періодично } \\
\text { проточні }\end{array}$ & $\begin{array}{l}\text { Частково- } \\
\text { проточні, } \\
\text { непроточні }\end{array}$ & $\begin{array}{l}\text { Непроточні, } \\
\text { частково- } \\
\text { проточні }\end{array}$ & $\begin{array}{l}\text { Частково- } \\
\text { проточні }\end{array}$ \\
\hline $\begin{array}{l}\text { Мінералізація, } \\
\text { мг/дм }\end{array}$ & $300-400$ & $600-1000$ & $400-600$ & $100-200$ & $2000-7000$ & $3000-7000$ \\
\hline $\begin{array}{l}\text { Переважаючий } \\
\text { тип } \\
\text { заростання }\end{array}$ & Зональний & $\begin{array}{l}\text { Зонально- } \\
\text { суцільний, } \\
\text { суцільний }\end{array}$ & Зональний & Зональний & Зональний & $\begin{array}{l}\text { Зональний, } \\
\text { суцільний }\end{array}$ \\
\hline $\begin{array}{l}\text { Індикаторні } \\
\text { види }\end{array}$ & $\begin{array}{l}\text { Potamogeton } \\
\text { perfoliatus } \\
\text { Potamogeton } \\
\text { gramineus } \\
\text { Batrachium } \\
\text { circinatum } \\
\text { Najas marina } \\
\text { Spirodela } \\
\text { polirrhyza } \\
\text { Nuphar lutea } \\
\text { Trapa } \\
\text { borysthenica } \\
\text { Typha laxmannii } \\
\text { Thelipteris } \\
\text { palustris }\end{array}$ & $\begin{array}{l}\text { Potamogeton } \\
\text { lucens } \\
\text { Potamogeton } \\
\text { natans } \\
\text { Stratiotes aloides } \\
\text { Trapa } \\
\text { borysthenica } \\
\text { Nymphaea alba }\end{array}$ & $\begin{array}{l}\text { Riccia fluitans } \\
\text { Potamogeton } \\
\text { natans } \\
\text { Potamogeton } \\
\text { compressus } \\
\text { Nymphaea alba } \\
\text { Alnus glutinosa }\end{array}$ & $\begin{array}{l}\text { Riccia fluitans } \\
\text { Ricciocarpus } \\
\text { natans } \\
\text { Utricularia } \\
\text { vulgaris }\end{array}$ & $\begin{array}{l}\text { Zannichelia } \\
\text { palustris } \\
\text { Scirpus } \\
\text { tabernaemontani }\end{array}$ & $\begin{array}{l}\text { Zannichelia } \\
\text { palustris } \\
\text { Batrachium } \\
\text { trichophyllum } \\
\text { Scirpus } \\
\text { tabernaemontani }\end{array}$ \\
\hline
\end{tabular}

Таблиця 2

Гідролого-гідроботанічні особливості озер долини середньої річки (Самари)

\begin{tabular}{|c|c|c|c|c|c|c|}
\hline \multirow{3}{*}{$\begin{array}{l}\text { Типи } \\
\text { Осер } \\
\text { особ- } \\
\text { ливості } \\
\text { озер }\end{array}$} & \multicolumn{4}{|c|}{ Заплава } & \multirow{3}{*}{$\begin{array}{c}\text { Арена } \\
\\
\text { Низько- } \\
\text { мінералізовані }\end{array}$} & \multirow{3}{*}{$\begin{array}{c}\text { 3-тя тераса } \\
\\
\text { Високо- } \\
\text { мінералізовані }\end{array}$} \\
\hline & \multirow{2}{*}{ Прируслові } & \multicolumn{2}{|c|}{ Центрально-заплавні } & \multirow{2}{*}{ Притерасні } & & \\
\hline & & $\begin{array}{c}\text { Великі та } \\
\text { середні }\end{array}$ & Малі лісові & & & \\
\hline $\begin{array}{l}\text { Особливості } \\
\text { гідрології }\end{array}$ & $\begin{array}{l}\text { Періодично } \\
\text { проточні }\end{array}$ & $\begin{array}{l}\text { Періодично } \\
\text { проточні, } \\
\text { непроточні }\end{array}$ & $\begin{array}{l}\text { Періодично } \\
\text { проточні, } \\
\text { непроточні }\end{array}$ & $\begin{array}{l}\text { Періодично } \\
\text { проточні }\end{array}$ & $\begin{array}{l}\text { Частково- } \\
\text { проточні }\end{array}$ & $\begin{array}{l}\text { Періодично } \\
\text { проточні, } \\
\text { непроточні }\end{array}$ \\
\hline $\begin{array}{l}\text { Мінералізація, } \\
\text { мг/дм }\end{array}$ & $1000-1600$ & $500-900$ & $500-900$ & $400-600$ & $100-200$ & $3000-40000$ \\
\hline Тип заростання & Зональний & Суцільний & $\begin{array}{l}\text { Розсіяно- } \\
\text { плямистий, } \\
\text { суцільний }\end{array}$ & $\begin{array}{l}\text { Зонально- } \\
\text { суцільний }\end{array}$ & $\begin{array}{l}\text { Зонально- } \\
\text { суцільний }\end{array}$ & $\begin{array}{l}\text { Зонально- } \\
\text { суцільний }\end{array}$ \\
\hline $\begin{array}{l}\text { Індикаторні } \\
\text { види }\end{array}$ & $\begin{array}{l}\text { Potamogeton } \\
\text { perfoliatus } \\
\text { Potamogeton } \\
\text { pectinatus } \\
\text { Nuphar lutea } \\
\text { Sium } \\
\text { latifolium }\end{array}$ & $\begin{array}{l}\text { Ceratophillum } \\
\text { submersum } \\
\text { Nymphaea alba } \\
\text { Lemna gibba } \\
\text { Wolffia arrysa }\end{array}$ & $\begin{array}{l}\text { Lemna } \\
\text { minor } \\
\text { Lemna gibba } \\
\text { Wolffia arrysa }\end{array}$ & $\begin{array}{l}\text { Ceratophillum } \\
\text { penthacantum } \\
\text { Nymphaea alba } \\
\text { Thelipteris } \\
\text { palustris } \\
\text { Alnus glutinosa }\end{array}$ & $\begin{array}{l}\text { Potamogeton } \\
\text { compressus } \\
\text { Utricularia } \\
\text { vulgaris } \\
\text { Hottonia palustris } \\
\text { Aldrovanda } \\
\text { vesiculesa } \\
\text { Stratiotes aloides } \\
\text { Thelipteris } \\
\text { palustris } \\
\text { Alnus glutinosa }\end{array}$ & $\begin{array}{l}\text { Zannichelia } \\
\text { palustris } \\
\text { Batrachium } \\
\text { trichophyllum } \\
\text { Ruppia maritima } \\
\text { Bolboschoenus } \\
\text { maritimus }\end{array}$ \\
\hline
\end{tabular}

Дніпра, Самари та Орілі відповідно до трьох озерних районів (рис. 1): Дніпровського, Самарського, Орільського.

Гідрологічні особливості озер долини Орілі відрізняються періодичною або незначною проточністю та меншим, ніж для озер Самари, гідрохімічним діапазоном (від 0,3 до 7 г/дм ${ }^{3}$ ).

Існують багаточисельні типології континентальних водойм, у тому числі й озер. Але для північної частини степової зони України, де озера мають невисоку чисельність та площу, окремої їх типології до цього часу не розроблено. Розробка типології озер враховує їх генезис, морфологію, гідрохімію та гідробіологію. Екологічний підхід до типології озер враховує їх сучасний стан та об'єднує водойми за розташуванням (розподіл за екологотопографічним профілем), гідрологічним, гідрохімічним режимами, ступенем та характером заростання.

Враховуючи існуючі типології водойм Європи (Gur'yanova, 1946; Hutchinson, 1975), водойм України 


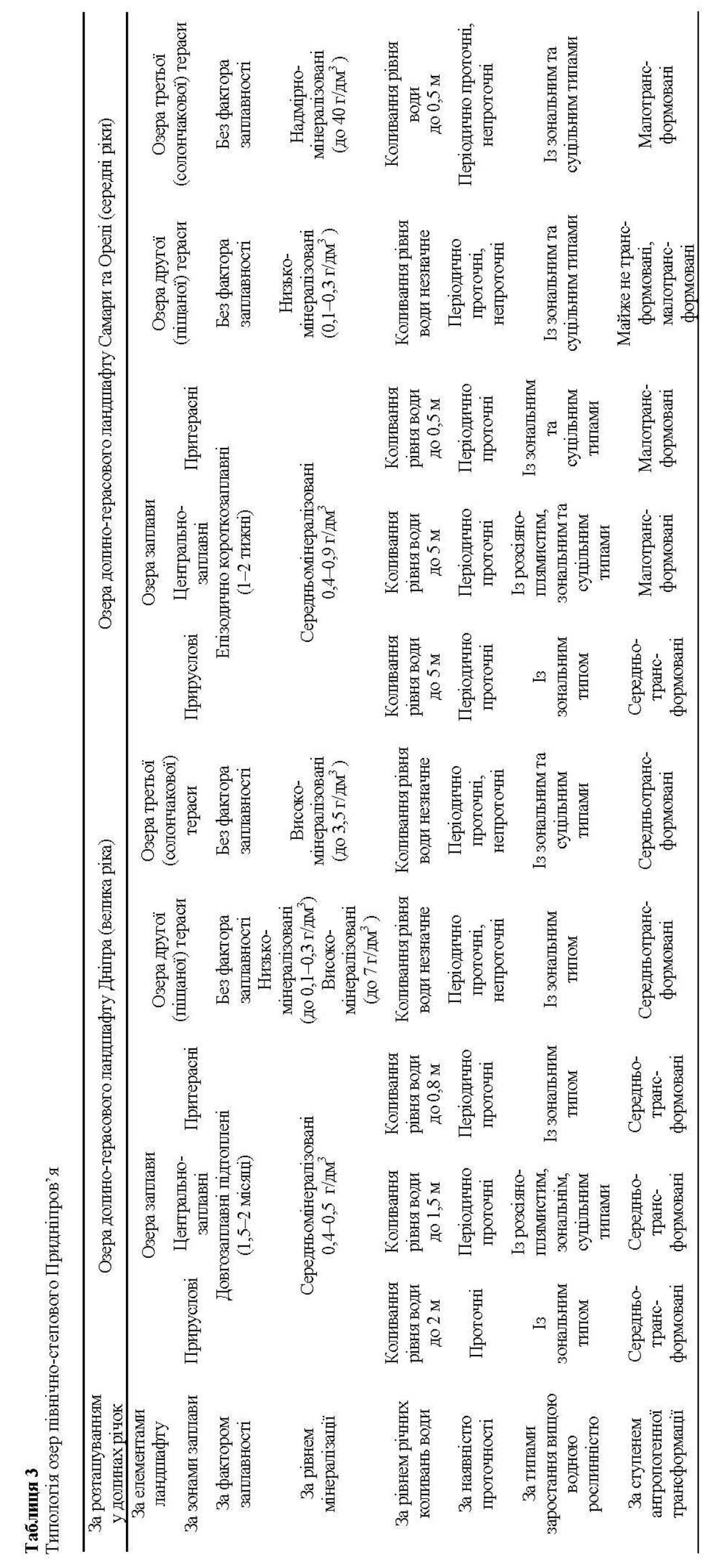


(Polishchuk, 1983) та типологій водойм Степу України (Sidel'nik, 1948) розроблено типологію озер північностепового Придніпров'я. Екологічний підхід до типології озер враховує їх сучасний стан та об'єднує водойми за розташуванням (розподіл за еколого-топографічним профілем), гідрологічним, гідрохімічним режимами, ступенем та характером заростання.

Типологія озер північно-степового Придніпров'я

А. Озера (великої ріки) долинно-терасового ландшафту Дніпра.

І. Озера заплави (середньозаплавні підтоплені):

1. Прируслові (озера Сомівка, В. Лопатка, М. Лопатка).

2. Центральнозаплавні (озера Оріхове, Литвинове, Відлоге) на Правобережжі - Діївські плавні.

3. Притерасні (озера Горбове, Сокілки, Мала Хатка, Солоне);

II. Озера другої (піщаної) тераси:

1. Низькомінералізовані (озера Шпакове, Карпенкове, Московське).

2. Високомінералізовані (озеро Сага).

III. Озера третьої тераси.

Високомінералізовані (озера Куряче, Одинковка),

Б. Озера (середніх річок) Самари та Орілі.

I. Озера заплави (короткозаплавні):

1. Прируслові (озера Оленеве, Довге)

2. Центральнозаплавні (озера Княгиня, Гайдамацьке, Федорівське)

3. Притерасні (озера Сорокособаче, Княгиня, Оленеве)

II. Озера другої (піщаної) тераси:

1. Низькомінералізовані (озера Караванище, Корчаче)

III. Озера третьої тераси:

1. Високомінералізовані (озера Булахівський Лиман, Солоний Лиман, Козачий лиман).

Екологічний підхід до типології озер враховує їх сучасний стан та об'єднує водойми за розташуванням (розподіл за еколого-топографічним профілем), гідрологічним, гідрохімічним режимами, ступенем та характером заростання.

Основними критеріями виділення типів озер у першу чергу було розташування їх у долинах категорій річок, у різних елементах ландшафту та зонах заплави, надалі фактор заплавності, рівень річних коливань води та проточність. Також були враховані: рівень мінералізації, ступінь антропогенної трансформації.

Просторова диференціація та склад рослинності озер залежить від розташування їх у певних елементах ландшафтів, віку цих водойм та рівня антропогенного навантаження. В залежності від цього вони представлені окремими типами заростання (Sidel'nik, 1948; Baranovskij, 2000). Рослинний покрив різних типів озер відрізняється за своєю просторовою диференціацією - типами заростання: розсіяно-плямистим, зональним, суцільним.

При виділенні типів озер також були враховані певні індикаторні види вищих водних рослин, наявність яких відповідає природним гідрологічним та гідрохімічним особливостям, а також практичній відсутності (озера арени підрайону Самарського бору) або різному ступеню антропогенної трансформованості водойми.

На основі наведених критеріїв виділено 11 типів озер (табл. 3). Для долини великої ріки виділено 6 типів: озера заплави (прируслові, центральнозаплавні, притерасні) 3 довгозаплавним режимом, озера другої (піщаної) тераси (від низькомінералізованих до високомінералізованих) та високомінералізовані озера третьої (солончакової) тераси.

Для долин середніх річок виділено 5 типів: озера заплави (прируслові, центральнозаплавні, притерасні) 3 епізодично короткозаплавним режимом, озера другої (піщаної) тераси (низькомінералізовані) та надмірномінералізовані озера третьої (солончакової) тераси.

\section{Висновки}

За розробленим районуванням озера північно-степового Придніпров'я розташовані в долинах річок Дніпра, Самари та Орілі відповідно до трьох озерних районів - Дніпровського, Самарського, Орільського.

На основі районування та гідролого-гідроботанічних особливостей - за розташуванням в долинах річок, елементами ландшафту, зонами заплави, фактором заплавності, рівнем мінералізації, рівнем річних коливань води, проточністю, типами заростання, ступенем антропогенної трансформації) виділено 11 типів озер: 6 типів для долини великої ріки та 5 типів для долин середніх річок.

Розроблена типологія озер може слугувати основою для диференційованого підходу щодо вивчення та характеристики рослинності озер та пов'язаних з ними біогідроценозів.

\section{References}

Baranovski, B., Roshchyna, N., Karmyzova, L., Ivanko, I. (2018). Comparison of commonly used ecological scales with Belgard Plant Ecomorph System. Biosystems Diversity, 26(4), 286291.

Baranovskij, B. A. (1988). Geobotanicheskoe rajonirovanie Zaporozhskogo vodohranilishcha. [Geobotanical zoning of the Zaporozhye reservoir]. Tez. dokl. II Vsesoyuz. konf. po vysshim vodnym i pribrezhnovodnym rasteniyam. Borok (in Russian).

Baranovskij, B. A., Voloshina, N. O. (2012). Analiz raritetnogo fondu flori sudinnih roslin Dniprovs'ko-Oril's'kogo prirodnogo zapovidnika [Analysis of the rare fund of the flora of shipwort dews of the Dniprovsky-Orylsky Nature Reserve]. Pitannya stepovogo lisoznavstva ta lisovoi rekul'tivacii zemel, 41, 2029 (in Ukrainian).

Baranovs'kij, B. O., Tarasov, V. V., Ivan'ko, I. A., Dubina, A. O., Roshchina, N. O. (2018). Analiz raritetnoi frakcii flori proektovanogo zakaznika zagal'noderzhavnogo znachennya «Samars'kij bir» [Analysis of the rare fractions of the floristic design reserve of the Western proprietary value "Samarsky Bir"]. Roslinnij svit u Chervonij knizi Ukraini: vprovadzhennya Global'noi strategii zberezhennya roslin: Materiali V Mizhnarodnoi konferencii. Herson. 139-142 (in Ukrainian).

Baranovs'kij, B. O., Voloshina, N. O. (2010). Analiz vodnoi ta priberezhnoi flori Diivs'kih plavniv [Analysis of water and coastal flora of Diivsky plavniv.]. Pitannya stepovogo lisoznavstva ta lisovoi rekul'tivacii zemel', 20-23 (in Ukrainian).

Baranovsky, B. A. (2000). Rastitel'nost' ruslovogo ravninnogo vodohranilishha [Vegetation of the channel of the plain reservoir]. Izdatel'stvo DNU, Dnepropetrovsk (in Russian).

Baranovsky, B. A. (2002). Flora vodoemov basseyna r. Samary [Flora reservoirs of Samara River Basin]. Pytannya stepovoho lisoznavstva ta lisovoyi rekultyivatsiyi zemel, 31, 90-103 (in Russian).

Baranovskyj, B. A., Loza, Y. M., Murzyna, T. A., Delyja, O. M. (2002). Sostav makrofytnoj rastytel'nosty pojmennyh vodoemov Prysamar'ja v zavysymosty ot gydrohymycheskogo rezhyma [The composition of the macrophytic vegetation of floodplain water bodies of the Pre-Samaria region depending on the hydrochemical]. Problemy ekologii' ta ekologichnoi' osvity. Mat. I mizhnarod. nauk. konf. Kryvyj Rig. 145-150 (in Russian).

Belgard, A. L. (1950). Lesnaya rastitelnost yugo-vostoka USSR [Forest vegetation of southeast Ukrainian SSR]. KSU, Kiev (in Russian).

Ekoflora Ukraini [Ecoflora of Ukraine] (2000-2010). Kyiv. B. 13, 5, 6 (in Ukrainian).

Flora Evropejskoj chasti SSSR [Flora of the European part of the USSR] (1974-1989). Pod red. A. A. Fedorova. Leningrad, Nauka. V. I-YIII (in Russian). 
Flora USSR [Flora USSR] (1935-1965). Kiev. V. I-XII (in Russian).

Flora Vostochnoj Evropy [Flora of Eastern Europe] (1996-2004). Pod red. N. N. Cveleva. - Sankt-Peterburg. V. IX-XI (in Russian).

Gur'yanova, E. F. (1946). K voprosu o principah klassifikacii kontinental'nyh vodoyomov i tipologii pojmennyh ozer [On the issue of the principles of classification of continental reservoirs and the typology of floodplain lakes]. Tr. yubilejnoj nauchnoj sessii. 193-210 (in Russian).

Junatov, A. A. (1964). Tipy i soderzhanie geobotanicheskih issledovanij, vybor probnyh ploshchadej $i$ zalozhenie ekologicheskih profilej [Types and contents of geobotanical research, selection of test plots and laying of environmental profiles]. Polevaya geobotanika, 3, 9-36 (in Russian).

Katanskaja, V. M. (1981). Vysshaja vodnaja rastytel'nost' kontynental'nyh vodoemov SSSR [Higher aquatic vegetation of the continental reservoirs of the USSR]. Leningrad (in Russian).

Manyuk, V. V., Baranovs'kij, B. O., Roshchina, N. O. (2018). Suchasnij stan ta bagatorichna dinamika flori prirodnogo zapovidnika "Dniprovs'ko-Oril's'kij" [The current state and the most dynamic dynamics of the natural reserve "DniprovskyOrylsky"]. Dnipro (in Ukrainian).

Mosyakin, S. L., Fedoronchuk, M. M. (1999). Vascular plants of Ukraine (Nomenclatural checklist). Naukova dumka, Kyiv, $346 \mathrm{pp}$.

Opredelitel vysshih rastenij Ukrainy [The determinant of vascular plants of Ukraine] (1987). Nauk. dumka, Kiev (in Russian).

Polevaya geobotanika [Field geobotany] (1964). Moskva; Leningrad. V. 3 (in Russian)

Polishchuk, V. V., Izumnova, L. V. (1983). O klasifikacii ozer i ozeropodobnyh vodoyomov Ukrainy [On the classification of lakes and lake-like reservoirs of Ukraine]. Gidrobiolog.zhurnal, 2, 100-104 (in Russian).

Ramenskyj, L. G. (1938). Vvedenye v kompleksnoe pochvennogeobotanycheskoe yssledovanye zemel' [Introduction to a comprehensive soil-geobotanical study of land]. Moscow, Sel'hozgyz (in Russian).

Raspopov, I. M. (1985). Vysshaya vodnaya rastitel'nost' bol'shih ozer Sev.-Zapada SSSR [Higher aquatic vegetation of large lakes in the North-West of the USSR]. Leningrad, Nauka (in Russian).

Roshchyna, N. O. (2016). Mnogoletnyaya dinamika flory ozer pojmy Dnepra V predelah Severnoj Stepi [Long-term dynamics of the flora of the Dnieper floodplain lakes within the Northern Steppe]. Sbornik materialov XI Mezhdunarodnoj nauchnoj konferencii studentov i molodyh uchenyh «Nauka i obrazovanie - 2016». Astana. 953-956 (in Russian).

Roshchyna, N. O. (2018). Suchasnij stan ta antropogennoklimatichna transformaciya roslinnosti ozer Pivnichnostepovogo Pridniprov'ya [The current state of anthropogenic-climatic transformation of the growth of the lakes of the Pivnichno-Steppe Dnieper.]. Ecology and Noospherology, 29(2), 40-51 (in Ukrainian).

Tarasov, V. V., Baranovskyj, B. A. (2003). Dopolnenye k flore Prysamar'ja [Addition to the prisamarya flora]. Pytannja stepovogo lisoznavstva ta lisovoi' rekul'tyvacii' zemel', 7, 82-92 (in Russian).

Schindler, S., O’Neill, F. H., Biry, M., Damm, C., Gasso, V., Kanka, R., Sluis, T., Krug, A., Lauwaars, S. G., Sebesvari, Z at all. (2016). Multifunctional floodplain management and biodiversity effects: a knowledge synthesis for six European countries. Biodivers conservi, 25, 1349-1382.

Sidel'nik, N. A. (1948). Tipy zarastaniya vodoemov doliny porozhistogo Dnepra i Samary Dneprovskoj [Types of overgrowing of reservoirs in the valley of the rapids of the Dnieper and Samara of the Dnieper.]. Vestnik NII in-ta gidrobiol. Dn-skogo un-ta, 8, 9-11 (in Russian).

Varenko, N. I. (1987). Gidrohimicheskij rezhim pojmy vodoyomov srednego Dnepra [Hydrochemical regime of the floodplains of the middle Dnieper]. Gidrobiologicheskij zhurnal, 1, 99-103 (in Russian).

Varenko, N. I., Kovtun, T. N., Murzina, T. A. (1992). Izmenenie himicheskogo sostava vody $\mathrm{r}$. Samara [Change in the chemical composition of the water of the river Samara]. Gidrobiolog. Zhurn., 5, 93-98 (in Russian).

Voloshyna, N. O. (2014). Porivnjal'nyj analiz flory ozer dolyny Samary v rajoni Prysamars'kogo biosfernogo stacionaru [Comparative analysis of the flora of the Samara Valley lakes near the Prisamara Biosphere Hospital]. Visnyk Harkivs'kogo nacional'nogo universytetu im. Karazina, 1100, 235-241 (in Ukrainian).

Vyznachnyk roslyn Ukrai'ny [Determinant of plants of Ukraine] (1965). Kyiv (in Ukrainian).

Zhadin, V. I., Gerd, S. V. (1961). Reki, ozera i vodohranilishcha SSSR [Rivers, lakes and reservoirs of the USSR]. Ih fauna i flora. Moscow, Gosuchpedizd (in Russian). 